\title{
Zingiber zerumbet flower stem postharvest characterization ${ }^{(1)}$
}

\author{
CHARLESTON GONÇALVES ${ }^{(2)}$, CARLOS EDUARDO FERREIRA DE CASTRO(2), \\ ANA CECILIA RIBEIRO DE CASTRO(3); VIVIAN LOGES(4)
}

\begin{abstract}
About the Zingiber zerumbet little is known about its cut flower postharvest and market, despite its high ornamental potential. The inflorescences, which resemble a compact cone, emerge from the base of the plants and start with green color changing to red with the age. This study objective was to characterize floral stem of ornamental ginger in two cultivate conditions and to evaluate the longevity of those submitted to post-harvest treatments. Flower stems were harvest from clumps cultivated under full sun and partial shade area, and were submitted to the postharvest treatments: complete flower immersion in tap water (CFI) or only the base stem immersion (BSI). The flower stems harvested from clumps at partial shade presented higher fresh weight, length and diameter of the inflorescences compared to flower stems harvested from clumps at full sun area. The flower stem bracts cultivated in full sun area changed the color from green to red 10.69 and 11.94 days after BSI and CFI postharvest treatments, and the vase life were 22.94 and 28.19 days, respectively. Flower stem harvest in partial shade area change the color only after 18.94 and 18.43 days and the vase life durability was 27.56 and 31.81, respectively. The complete immersion of the flower stem increase the vase life durability in 5.25 and 4.25 days compared to flowers kept with the stem base immersed only, in flower stems harvested from clumps cultivated in full sun area and partial shade area, respectively. Flower stems harvested from clumps cultivated in partial shade area and completely immerse in tap water during 3 hours increase the vase life durability in 8.87 days compared to flowers harvested from clumps cultivated in full sun area and base immersed only.
\end{abstract}

Keywords: flower durability, ginger, hydration, tropical cut flower, Zingiberaceae.

\section{RESUMO}

Caracterização pós-colheita de hastes florais Zingiber zerumbet

Apesar do alto potencial ornamental, pouco se sabe sobre o cultivo, pós-colheita e mercado do Zingiber zerumbet. As inflorescências, que aparentam um cone, emergem da base da planta, sendo inicialmente de coloração verde passando para vermelho com o desenvolvimento. O objetivo deste trabalho foi caracterizar hastes florais de gengibres em duas condições de cultivo e avaliar a longevidade dessas submetida a tratamentos pós-colheita. Hastes florais foram colhidas de touceiras cultivadas a pleno sol e parcialmente sombreadas e foram submetidas a dois tratamentos pós-colheita: hastes florais completamente imersas em água (CFI) e apenas a base da haste imersa em água (BSI). As hastes florais colhidas de touceiras cultivadas parcialmente sombreadas apresentaram valores mais altos para peso fresco, comprimento e diâmetro das inflorescências em relação as hastes florais colhidas de touceiras cultivadas a pleno sol. As brácteas das hastes florais colhidas de touceiras cultivadas a pleno sol, apresentaram mudança da cor verde para avermelhada aos 10,69 e 11,94 e a durabilidade pós-colheita foi de 22,94 e 28,19 dias após o tratamento póscolheita de BSI e CFI, respectivamente. A mudança de cor das brácteas em hastes cultivadas a meia sombra foi observada apenas após 18,94 e 18,43 dias, e durabilidade pós-colheita de 27,56 e 31,81, respectivamente. A completa imersão das hastes florais aumentou a durabilidade pós-colheita em 5,25 e 4,25 dias em comparação com apenas a imersão da base, em hastes florais colhidas de touceiras cultivadas a pleno sol e meia sombra, respectivamente. Desta forma, a colheita de hastes florais de cultivos de meia sombra e a imersão destas em água, proporcionou incremento em 8,87 dias na durabilidade pós colheita em comparação colhidas em cultivos a pleno sol e apenas a base imersa em água, sendo descartada aos 31,81 dias.

Palavras-chave: flores tropicais, Zingiberaceae, ginger, durabilidade pós-colheita, hidratação.

\section{INTRODUCTION}

The Zingiber genus, Zingiberaceae family, comprises about 150 species. Some of them have ornamental, aromatic or medicinal characteristics. Species with ornamental value as cut flowers should presents vigorous plant developing, high postharvest durability and bright colorful bracts (KASARKAR and KULKARNI, 2011).
Z. zerumbet is commonly known in Brazil as maraca or pine cone and is grown as cut flower. This species has an upright and vigorous habit growth that range from 1.20 to $2.20 \mathrm{~m}$ in height. In two years of cultivation the clump area ranges from 1.20 to $1.80 \mathrm{~m}^{2}$ (THEILADE, 1999).

The leaves are sessile or petiolated, simple, alternate, lanceolate, with 0.20 to $0.60 \mathrm{~m}$ in length, normally green in color, but some genotypes are variegated. The

\footnotetext{
DOI: http://dx.doi.org/10.14295/oh.v23i2.956

${ }^{(1)}$ Received in 30/08/2016 and accepted in 26/04/2017

(2) Instituto Agronômico (IAC), Centro de Horticultura, Campinas-SP, Brazil. *Corresponding author: charleston@iac.sp.gov.br

(3) Embrapa Agroindústria Tropical (CNPAT), Fortaleza-CE, Brazil.

(4) Universidade Federal Rural de Pernambuco, Recife-PE, Brazil.

Licensed by CC BY 4.0
} 
inflorescences, which resemble a compact cone, emerge from the base of the plants. The bracts are initially green changing color to red with aging and is produced at the apex of a green stem that emerged from the soil (SABU and SKINNER, 2005). That gradual bracts color change add exoticity to the specie. The flowers are cream and ephemeral, opening daily, from base to apex, during inflorescence maturation process. It is a plant with dormancy during low temperature periods.

To date, there are no references on postharvest treatments for Z. zerumbet. However, for Z. spectabile, with similar inflorescence to $Z$. zerumbet, more information is available, e.g.: Dias and Castro (2009) observed that the use of preservative solutions with sacarose $(0,2,4$, $8,16$ and $32 \%)$ and citric acid $\left(200 \mathrm{mgL}^{-1}\right)$, or even an inflorescence pulverization with of citocinine $\left(200 \mathrm{mgL}^{-1}\right)$ and carnauba wax (18\% soluble solids) were not required applicable to $Z$. spectabile since their flowers properly harvested have a longevity of about 20 days; while Coelho et al. (2012) concluded that pulsing with Hydraflor-100® (manufacturer) provided 12 days postharvest durability for Z. spectabile.

The loss of quality of tropical cut flowers and, consequently, the vase life, may result from one of several causes, including symptoms such wilting of inflorescence parts, flower or bract abscission, bending of the inflorescence and bract color alteration. Many factors can potentially affect vase life, e.g.: the growth condition as the cultivation in partial shade instead of at full sun area could improve the flower stem quality (CLARK and WARNER, 2000). The hydration treatment after the harvest by the complete immersion of the flower stem improve postharvest durability, as recommend by Loges et al. (2005) to Z. spectabile.

Collectively, this study objective was to characterize $Z$. zerumbet flower stems from areas cultivated in full sun and partial shade condition and submitted to two postharvest treatments and its potential of use.

\section{MATERIAL AND METHODS}

The experiment used harvested stems from plants belonging to the Instituto Agronomico (IAC) collection, located in Ubatuba, São Paulo State, latitude 2326'02' S, longitude $45^{\circ} 04^{\prime} 16^{\prime \prime} \mathrm{W}$, with an average annual rainfall of 2,700 $\mathrm{mm}$ and 6 meters above the sea level.

Mature, healthy and undamaged flower stems were harvested early in the morning, from two years old clumps, cultivated in full sun and partial shade area (cultivated a long a grove, avoiding direct sunlight). The flower stems were evaluated for stem weight at harvest (SWH), stem weight after standardization (SWS) at $35 \mathrm{~cm}$, flower stem length (FSL), flower stem diameter (FSD), taken in the flower stem middle portion, inflorescence length (IL), inflorescence diameter (ID), taken in middle portion. Data was recorded in grams and for weight and centimeter for length and diameter.

After the biometrical evaluation, the flower stems were submitted to two different postharvest treatments: complete flower stem immersion (CFI) and base stem immersion (BSI) in tap water for 3 hours. Four replications with four flower stems per replication was used in each treatment.

Subsequently to the postharvest treatments, the stems were placed in vases with $500 \mathrm{ml}$ of tap water in a room with controlled conditions: average temperature $21^{\circ} \mathrm{C}$; relative humidity $60 \%$ and $12 \mathrm{~h}$ photoperiod. The flower stems were evaluated every two days and the following parameters observed: days for the bracts change from green to red (DBC); vase life days (VLD); stem weight at the discard point (SWD); Percentage of stem weight lost at the discard point ( $\%$ SWL). The flowers persistence inside the bracts were also observed.

Vase life was considered finished when the inflorescence showed either or any of those factors: loss of flower stem firmness, i.e.: ability to maintain an upright position; inflorescence darkening; decay of the inflorescence apex; drying the bracts edges. Vase life was classified as long and with high potential of use $(>20$ days), intermediary (between 10 and 20 days) and short ( $<10$ days).

The experimental design was in a randomized blocks, with four treatments in a factorial arrangement $2 \times 2$ (full sun and partial shade area $\mathrm{x}$ two postharvest treatments). Data was submitted to analysis of variance and the parameters averages were compared between treatments using the Tukey Test at 5\% probability, using the GENES computer software (CRUZ, 2013).

\section{RESULTS AND DISCUSSION}

The flower stems harvested from clumps at partial shade area present higher values from stem weight at harvest (SWH), stem weight after standardization (SWS), flower stem length (FSL) and diameter (FSD) compared to flower stems harvested from clumps at full sun area. The inflorescence length (IL) and diameter (ID) were similar between the two growth conditions (Figure 1). 

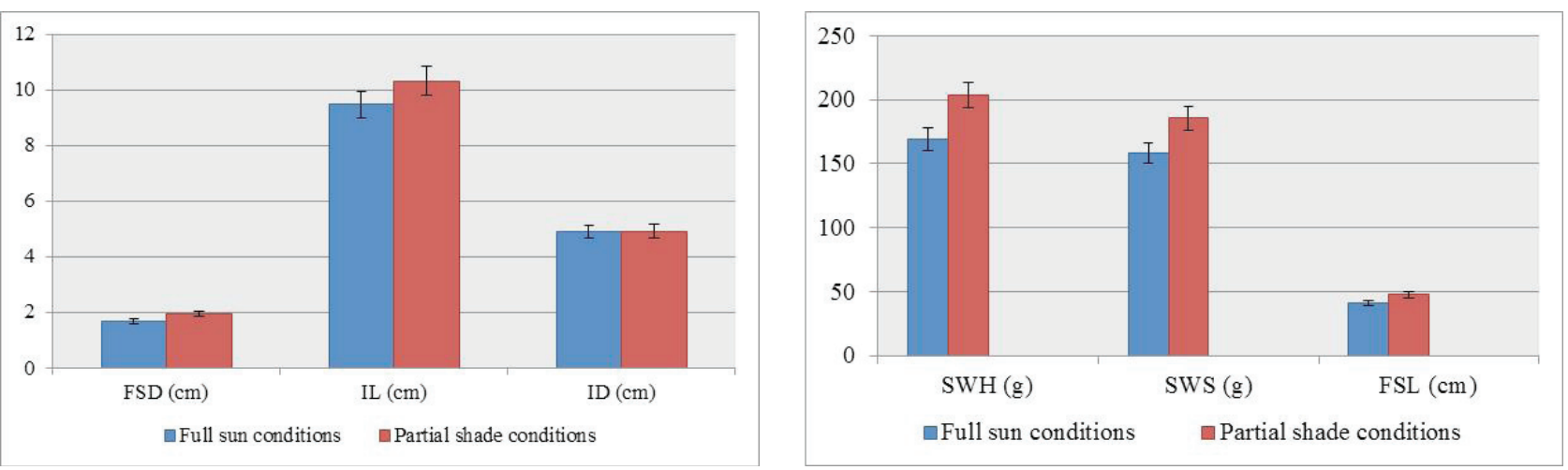

Figure 1. Zingiber zerumbet flower stem characterization cultivated in full sun and partial shade conditions: SWH Stem weight at the harvest (g); SWP - Stem weight patronized (g); FSL - Flower stem length (cm); FSD - Flower stem diameter $(\mathrm{cm})$; IL - Inflorescence length (cm); ID - Inflorescence diameter $(\mathrm{cm})$.

Z. zerumbet inflorescences are green in the field however it changes completely to red along the time (SABU and SKINNER, 2005). Similarly, these senescence symptoms were observed in $Z$. zerumbet flower stems after harvest, regardless color change, the flower stems had quality.

The flower stems harvested from full sun area that were complete immersed (CFI) or that had only the base stem immersed (BSI) in tap water, present change color in the bracts after 11.94 and 10.69 days, respectively (Table 1). In flower stems harvested from partial shade growth condition the color change was observed later in time, i.e.: 18.43 and 19.94 days, from CFI and BSI respectively.

Table 1. Zingiber zerumbet flower stem cultivated in full sun and partial shade conditions and submitted to postharvest treatment of complete flower stem immersion (CFI) and base stem immersion (BSI) in tap water for 3 hours.

\begin{tabular}{|c|c|c|c|c|c|c|c|c|c|c|}
\hline & \multicolumn{2}{|c|}{ DBC* } & \multicolumn{2}{|c|}{ VLD } & \multicolumn{2}{|c|}{ SWP (g) } & \multicolumn{2}{|c|}{ SWD (g) } & \multicolumn{2}{|c|}{$\%$ SWL } \\
\hline Full sun conditions + CFI & 11.94 & $\mathrm{~b}$ & 28.19 & $\mathrm{~b}$ & 143.03 & $\mathrm{~b}$ & 124.42 & $\mathrm{~b}$ & 13.01 & a \\
\hline Full sun conditions + BSI & 10.69 & $b$ & 22.94 & $\mathrm{c}$ & 173.06 & $\mathrm{a}$ & 147.51 & $\mathrm{a}$ & 14.71 & a \\
\hline Partial shade conditions + CFI & 18.43 & a & 31.81 & $\mathrm{a}$ & 182.67 & $\mathrm{a}$ & 157.39 & $\mathrm{a}$ & 19.53 & $\mathrm{~b}$ \\
\hline Partial shade conditions + BSI & 18.94 & a & 27.56 & $\mathrm{~b}$ & 188.93 & $\mathrm{a}$ & 152.25 & $\mathrm{a}$ & 13.91 & a \\
\hline
\end{tabular}

* DBC - days for the bracts change the color green to red; VLD - Vase life days; SWP - Stem weight patronized (g); SWD - Stem weight at the discard point; $\% \mathrm{SWL}-$ Percentage of stem weight lost at the discard point; Means followed by the same small letter in the column did not differ by Tukey Test $(p<0,05)$.

In relation to vase life days (VLD), which ranged from 22.94 to 31.81 (Table 1), there were significant differences between treatments. The stems submitted to the treatment partial shade conditions + CFI presented a longer longevity
(31.81 VLD) in contrast the stems submitted to the treatment full sun area + BSI presented a lower longevity (22.94 VLD). The treatments partial shade conditions + BSI (27.88 VLD) and full sun area + CFI (28.19) did not differ from each other.
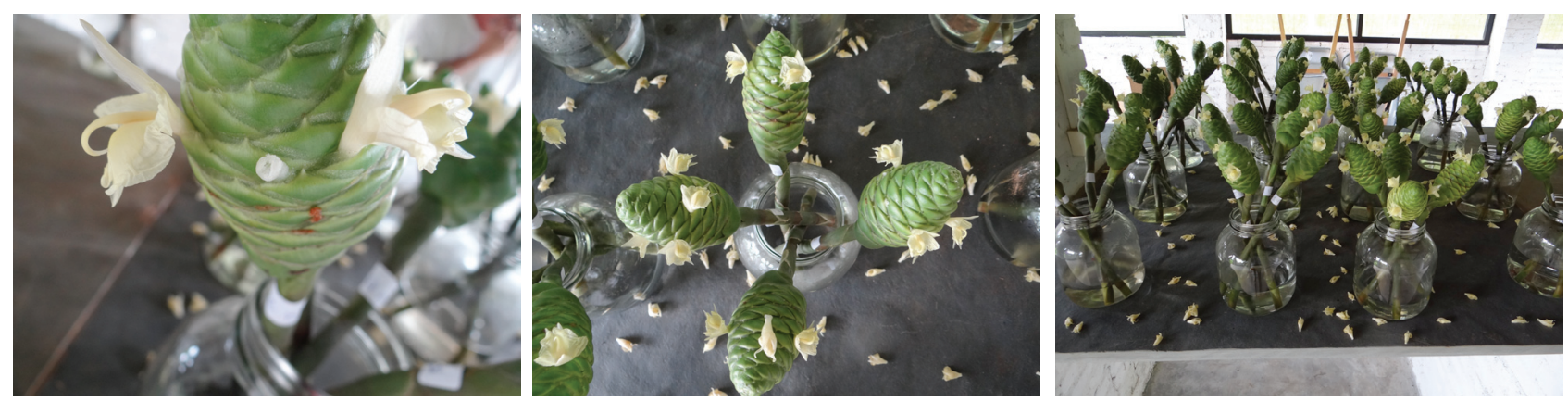

Figure 2. Flowers opening in bracts and falling down from inflorescence of Zingiber zerumbet flower stem. 
During vase life assessment, it was observed continuous flower opening and fallen from the inflorescence bracts and its indicated the necessity of cleaning the flowers (Figure 2). Darkening and drying of the bracts edges were observed in the flower stem harvest for the two cultivate area and submitted to the postharvest treatments.

Concerning to stem weight after standardization (SWS), a higher mass was observed in the stems harvest for partial shade area (182.67 and $188.93 \mathrm{~g})$. This lower mass observed in stems from full sun area could be related to a greater evapotranspiration and consequent stress, common to other Zingiberales like bananas (ROBINSON and GALÁN SAÚCO, 2010).

The flowers stem weight lost at the discard point (SWL) were of 13.01 to $19.53 \%$ in comparing with the flowers stem weight after standardization (SWS). The higher loss of weight at the discard point was observed in flower stem cultivated in partial shade condition with complete immersion of flower stem in water $(19.53 \%)$, the same treatment that present the higher VLD. The extra vase life days' result in higher weight loss.

Collectively, Z. zerumbet flower stems harvested from partial shade area presented superior overall quality compared to stems from full sun area, with more days to bracts turn red and 8.87 days of extra vase life. The complete immersion of the flower stem in water during 3 hours increased the vase life, in approximately 4.25 days of $Z$. zerumbet flowers stem harvest from clumps cultivated at partial shade and in 5.25 days in full sun area.

\section{CONCLUSIONS}

Zingiber zerumbet has potential use as cut flower. Cultivation at partial shade area produces Zingiber zerumbet flower stems with highest quality and postharvest durability. Independent of the cultivation system, the complete immersion of the flower stem in tap water during 3 hours increase the vase life durability of Zingiber zerumbet.

\section{ACKNOWLEDGMENTS}

This research was supported/partially supported by CAPES (Coordenação de Aperfeiçoamento de Pessoal de Nível Superior), CNPq (Conselho Nacional de Desenvolvimento Científico e Tecnológico - "National Counsel of Technological and Scientific Development”).

\section{AUTHORS CONTRIBUTION}

C.E.F.C.: Creation of the idea, literature review and data collection, obtaining of funds and materials, preparation of the basic text of the work and important suggestions incorporated to the manuscript final version. C.G: Creation of the idea, obtaining of funds and materials, orientation and coordination of the work, laboratory analysis and data collection, important suggestions incorporated to the manuscript final version, statistical analysis of data. A.C.R.C: Creation of the idea, data collection, obtaining of funds and materials, literature review, preparation of the text of the work and important suggestions incorporated to the manuscript final version. V.L.: Creation of the idea, obtaining of funds and materials, Laboratory analysis and data collection, preparation of the text of the work and important suggestions incorporated to the manuscript final version.

\section{REFERENCES}

CLARK, R.J.; WARNER, R.A. Production and marketing of japanese ginger (Zingiber mioga) in Australia. Kingston: RIRDC, 2000. 19p.

COELHO, L.L.; CARNEIRO, D.N.M.; PAIVA, P.D.O.; CARNEIRO, L.F. Soluções conservantes e pulsing na póscolheita de Zingiber spectabile. Pesquisa Agropecuária Tropical, v.42, n.4, p.482-485, 2012. DOI: <http://dx.doi. org/10.1590/S1983-40632012000400016>

DIAS, G.M.; CASTRO, C.E.F. Longevidade pós-colheita de Zingiber spectabile Griff. Revista Brasileira de Horticultura Ornamental, v.15, n.2, p.127-131, 2009. DOI: <http://dx.doi.org/10.14295/rbho.v15i2.493>

KASARKAR, A.R.; KULKARNI, D.K. Phenological studies of Family Zingiberaceae with special reference Alpinia and Zingiber from Kolhapur region. Bioscience Discovery, n.2, v.3, p.322-327, 2011.

LOGES, V.; CASTRO, A.C.R.; TEIXEIRA, M.C.F.; COSTA, A.S. Colheita, pós-colheita e embalagem de flores tropicais em Pernambuco. Horticultura Brasileira, v.23, n.3, p.699-672, 2005. DOI: < http://dx.doi.org/10.1590/ S0102-05362005000300001>

ROBINSON, J.C.; GALÁN SAÚCO, V. Phenological and physiological responses. In: ROBINSON, J. C. GALÁN SAÚCO, V. Bananas and plantains. Oxford: CAB International, 2010. p.89-114.

SABU, M.; SKINNER, D. Other economically important Zingiber species. In: RAVINDRAN, P.N.; BABU, K.N. Ginger - The genus Zingiber. New York: CRC Press, 2005. 680p.

THEILADE, I. A synopsis of the genus Zingiber (Zingiberaceae) in Thailand. Nordic Journal of Botany, v.19, p.389-410, 1999. DOI: <10.1111/j.1756-1051.1999. tb01220.x> 